\title{
The Influence of Organizational Culture and Work Environment on Employee Performance with Job Satisfaction as Mediation (Case Study on West Jakarta Mayor's Office Employees)
}

\author{
Vebina Desi EkaWati, M. Havidz Aima, and Ikramina Larasati Hazrati
}

\section{ABSTRACT}

This study aims to analyze the influence of organizational culture and work environment on employee performance with job satisfaction as a mediation. The use of research methods with quantitative methods. The use of the research population is the West Jakarta Mayor's Office employees, totaling 130 employees, with a total sample of 100 employees. The use of data analysis method with Structural Equation Model-Partial Least Square. The results found that the work environment has no significant impact on employee performance, organizational culture positively affects work fulfillment and worker execution, the workplace positively affects work fulfillment, job satisfaction positively affects representative execution, job satisfaction there is influence mediates organizational culture variables and work environment variables. on employee performance.

Keywords: employee performance, job satisfaction, organizational culture, work environment.

\section{INTRODUCTION}

In the world of government, it must be able to create the performance of employees who have high integrity so that the agency can develop. Achievements can be used as benchmarks for the performance of employees. The success of the agency is very dependent on the individual workers because individuals are needed to support the success of the agency so that it can grow and develop. In addition to the individual factors, the application of good culture is also very necessary so that the agency can run well.

The purpose of implementing a good organizational culture is so that agencies can create employees who have a better culture in the organization. The creation of a better culture can improve employee performance. In addition to the existence of culture within an organization, of course, it can create a comfortable work environment for employees. The Jakarta Mayor's Office has 130 employees.

Research by [1] explains that authoritative culture has a positive influence on job fulfillment. An examination led by [2] explained that between work environment and job satisfaction there was a significant positive direct effect.

Then the next researcher according to [3] explains that organizational culture has a significant positive effect on employee performance. Different research by [4] suggests that organizational culture has no critical impact on representative execution. According to researchers [5], the work environment has a positive directional effect on employee performance. Then the next researcher [6] explained that job satisfaction had a positive directional effect on employee performance. Further researchers according to [7] explained that there was a negative and significant effect of job satisfaction on employee performance. According to research [8] stated that hierarchical culture and workplace positively affect the work fulfillment of representatives of PT. Posmi Steel Indonesia. In line with the research.

According to research [9] shows that hierarchical culture, workplace, and job fulfillment simultaneously affect employee performance. Research conducted by [10] that organizational culture has a positive effect on employee performance through job satisfaction as a mediating variable.

According to [11] concluded that the work environment has a positive effect on employee performance through employee job satisfaction BULOG East Java Regional Division.

\section{LITERATURE REVIEW AND HYPOTHESIS DEVELOPMENT}

\section{A. Employee Performance}

Meanwhile [12] states that employee performance is the process of individual achievement related to the tasks that have been given. However, [13] argues that employee performance is the result of work achievement when viewed from the quality and quantity of a worker when completing his or her duties that are in accordance with the responsibilities given to the worker. Based on [13] suggests 
that aspects of employee performance are work quality, quantity, responsibility, cooperation, and initiative.

\section{B. Organizational Culture}

According to [14] said that organizational culture can affect the effectiveness and performance of the organization. This means that, with the creation of a good organizational culture, better employee performance will be formed. Meanwhile, according to [14] there are 5 aspects of organizational culture which include innovation and risktaking courage (Innovation and risk tasking), paying attention to each detail section (Attention to detail), result-oriented (Outcome orientation), human-oriented (People orientation), team (Team orientation).

\section{Work Environment}

According to [15] shows that there are a number of elements that can influence the formation of a work environment situation in the workplace, including the presence of lighting, temperature, humidity, air circulation, and noise generated. In today's conditions, there are still many organizations that do not pay attention to environmental conditions in the workplace. So that it can make employees feel less comfortable and their performance will also decrease.

\section{Job Satisfaction}

According to [16] suggests that job satisfaction is the general behavior of an individual's job as a difference between the number of rewards earned by individuals and the number of rewards earned. Job satisfaction is an important thing that individuals have in doing their jobs. Each worker has different specifications, so the level of high and low satisfaction is also different so that it can have different impacts.

\section{E. Hypothesis Development}

Departing from the research gaps in previous studies and in accordance with the theoretical explanation above, Fig. 1 shows the conceptual model of the research to outline the following hypotheses:

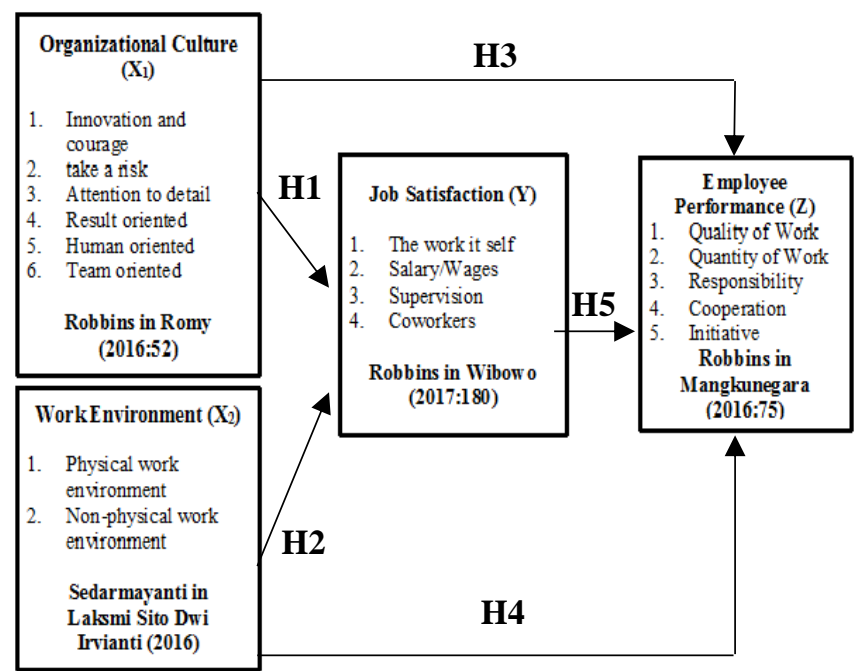

Fig. 1. The Conceptual Model.
H1: Organizational culture has a positive impact on job satisfaction.

$\mathrm{H} 2$ : The work environment has a positive impact on job satisfaction.

H3: Organizational culture has a positive impact on employee performance.

H4: The work environment has no significant impact on employee performance.

H5: Job satisfaction has a positive impact on employee performance.

\section{RESEARCH METHODOLOGY}

The research design used is causality analysis (cause and effect). The quantitative method according to [17] is used to show the description of each variable that can be done by analyzing the impact of the independent variable on the dependent variable, with the aim of testing the hypothesis. The method for obtaining this research data is by obtaining a survey using a questionnaire.

This research population uses a total of 130 employees of the West Jakarta Mayor's office. Determination of the number of samples using the solving formula as follows:

$$
n=\frac{N}{1+N(e)^{2}}
$$

$n=$ Research sample;

$N=$ Population;

$e=$ Error tolerance limit 5\%.

Then obtained several samples, namely:

$$
n=\frac{130}{1+130(0.5)^{2}}=100
$$

The use of this research is data analysis techniques assisted by the Smart PLS version 3.0 software. The Outer Model is useful for testing validity and reliability, while the Inner Model is useful for testing causality (testing hypotheses with predictive models). According to [18], PLS is an analytical method that cannot be assumed that data acquisition must be on a certain scale, which means that the number of samples can be small (< 100 samples).

\section{RESEARCH RESULT}

\section{A. Characteristics of Respondents}

Table 1. Presents the results of 100 respondents' responses based on demographic characteristics by classifying assessments by frequency, percentage, and average or mean (M) for each research variable.

The distribution of answers was based on the majority of gender, namely the female gender, which amounted to 56 employees with a percentage rate of $56 \%$. Meanwhile, the characteristics of respondents with $\mathrm{S} 1$ education are 70 employees with a presentation rate of $70 \%$. Characteristics of respondents based on tenure are dominated by $2-5$ years with a total of 37 employees and a percentage of $37 \%$. And the characteristics of respondents based on employees, namely 
permanent employees, amounting to 69 employees with a percentage of $69 \%$.

TABLE I: CHARACTERISTICS OF RESPONDENTS

\begin{tabular}{cccc}
\hline \hline Characteristics & Category & Frequency & Percent \\
\hline Gender & Male & 44 & $44 \%$ \\
& Female & 56 & $56 \%$ \\
\hline Age & 21-30 Years & 69 & $69 \%$ \\
& 31-40 Years & 17 & $17 \%$ \\
& 41-50 Years & 9 & $9 \%$ \\
& $>50$ Years & 5 & $5 \%$ \\
\hline Education & High School & 24 & $24 \%$ \\
& Associate's & 2 & $2 \%$ \\
& Degree & 70 & $70 \%$ \\
& Bachelor & 4 & $4 \%$ \\
\hline Working & Master & 37 & $37 \%$ \\
Experience & 2-5 Years & 17 & $17 \%$ \\
& 6-10 Years & 6 & $6 \%$ \\
& $11-15$ Years & 4 & $4 \%$ \\
& $16-20$ Years & 36 & $36 \%$ \\
\hline Employee & Pe Years & 69 & $69 \%$ \\
& Permanent & 31 & $31 \%$ \\
\hline Nemporary & 100 & $100 \%$ \\
\hline \hline
\end{tabular}

\section{B. Evaluate the Measurement Model (Outerm Model)}

The results of the calculation of the evaluation of the measurement model in this study indicate a loading factor value $>0.50$ that all indicators are valid and will be used in this study. To assess the validity of a construct, the AVE, CA and $C R$ values can be used.

TABEL II: Average VARiance Extracted Value (AVE), Cronbach's

\begin{tabular}{cccc}
\multicolumn{4}{c}{ AlPHA (CA), COMPOSITE RELIABILITY (CR) } \\
\cline { 2 - 4 } Variable & \multicolumn{3}{c}{ West Jakarta Mayor's Office } \\
\hline \hline $\begin{array}{c}\text { Organizational } \\
\text { Culture }\end{array}$ & 0.558 & CA & CR \\
$\begin{array}{c}\text { Work } \\
\text { Environment } \\
\text { Job }\end{array}$ & 0.624 & 0.912 & 0.926 \\
$\begin{array}{c}\text { Satisfaction } \\
\text { Employee }\end{array}$ & 0.514 & 0.953 & 0.959 \\
Performance & 0,582 & 0.958 & 0.962 \\
\hline \hline
\end{tabular}

$\mathrm{CA}$ and $\mathrm{CR}$ values $>0.7$. It can be seen that the AVE score for the organizational culture variable is 0.558 , the CA number is 0.912 and the $\mathrm{CR}$ number is 0.926 . The work environment variable has an AVE score of 0.624, a CA score of 0.953 , and a CR score of 0.959 . The job satisfaction variable has an AVE score of 0.514, a CA score of 0.958, and a CR number of 0.962. Meanwhile, employee performance has an AVE score of 0.582, a CA score of 0.962, and a CR score of 0.965 .

\section{Structural Model Evaluation (Inner Model)}

Fig. 2 shows that the path that has the most influence is the work environment path on job satisfaction. Below is the result of the calculation of the R Square test.
TABEL III: R-SQUARE TEST RESULTS

\begin{tabular}{ccc}
\hline \hline Variable & $\mathrm{R}^{2}$ & $\mathrm{R}^{2}$ Adjusted \\
\hline \hline $\mathrm{Y}$ & 0,415 & 0,403 \\
$\mathrm{Z}$ & 0,515 & 0,500 \\
\hline \hline
\end{tabular}

Considering the consequences of the R-Square test which can be found in the results of the presentation of Table III that the job fulfillment variable can be clarified by hierarchical culture and workplace factors, $41.5 \%$. Meanwhile, the remaining $58.5 \%$ is contributed by other variables. not included in this research.

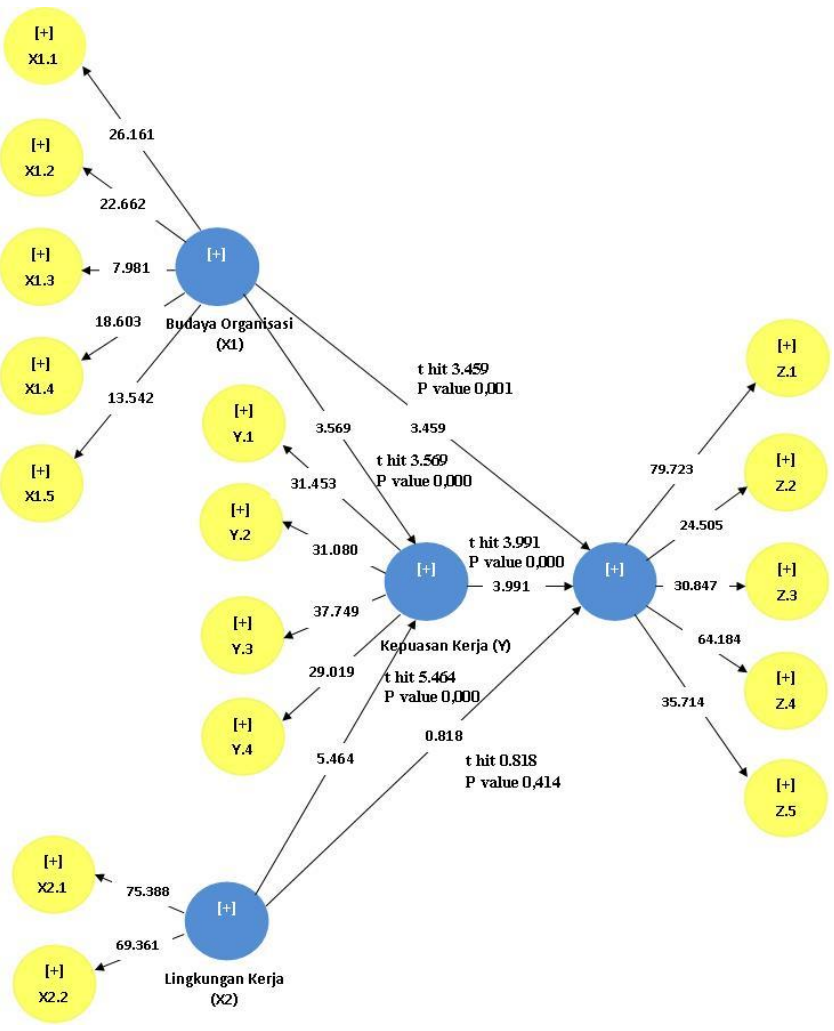

Fig. 2. Path Coefficient Measurement Model.

The $\mathrm{R}^{2}$ value of employee performance has a value of 0.515 or $51.5 \%$. This means that the variables of employee performance can be explained by the variables of organizational culture, work environment, and job satisfaction have a value of $51.5 \%$. while the rest has a value of $48.5 \%$.

Organizational Culture has an effect size in the moderate category on Job Satisfaction. Furthermore, the work environment has an effect size in the moderate category on job satisfaction.

Organizational Culture has an effect size in the moderate category on Employee Performance. While the work environment variable has an effect size in the small category on employee performance. Then the variable work fulfillment has an impact size in the moderate class on employee performance. The following hypothetical values can be shown in Table $\mathrm{V}$ below.

TABEL IV: EFFECT SIZE TEST RESULTS (F2)

\begin{tabular}{cccc}
\multicolumn{4}{c}{ TABEL IV: EFFECT SIZE TEST RESULTS (F2) } \\
Influence & $\mathrm{f}^{2}$ & Criteria & Description \\
\hline \hline Organizational Culture $\rightarrow$ Job Satisfaction & 0,153 & & Moderate \\
Work Environment $\rightarrow$ Job Satisfaction & 0,343 & $\geq 0,02$ (kecil) & Moderate \\
Organizational Culture $\rightarrow$ Employee Performance & 0,178 & $\geq 0,15$ (moderat) & Moderate \\
Work Environment $\rightarrow$ Employee Performance & 0,010 & $\geq 0,35$ (besar) & Small \\
Job Satisfaction $\rightarrow$ Work Environment & 0,243 & & Moderate \\
\hline \hline
\end{tabular}


TABEL V: PATH COEFFICIENT TEST RESUlTS

\begin{tabular}{cccccc}
\hline \hline Path & $\begin{array}{c}\text { Original } \\
\text { Sample (O) }\end{array}$ & $\begin{array}{c}\text { Sample } \\
\text { Mean (M) }\end{array}$ & $\begin{array}{c}\text { Standard } \\
\text { Deviation } \\
\text { (STDEV) }\end{array}$ & $\begin{array}{c}\text { T Statistics } \\
(\mid \mathrm{O} / \text { STDEV })\end{array}$ & P Values \\
\hline$(\mathrm{X} 1)->(\mathrm{Y})$ & 0,315 & 0,304 & 0,088 & 3,569 & 0,000 \\
$(\mathrm{X} 1)->(\mathrm{Z})$ & 0,332 & 0,321 & 0,096 & 3,459 & 0,001 \\
$(\mathrm{Y})->(\mathrm{Z})$ & 0,448 & 0,457 & 0,112 & 3,991 & 0,000 \\
$(\mathrm{X} 2)->(\mathrm{Y})$ & 0,472 & 0,488 & 0,086 & 5,464 & 0,000 \\
$(\mathrm{X} 2)->(\mathrm{Z})$ & 0,083 & 0,080 & 0,102 & 0,818 & 0,414 \\
\hline \hline
\end{tabular}

TABEL VI: INDIRECT EFFECT TEST RESULTS

\begin{tabular}{|c|c|c|c|c|c|}
\hline Influence & $\begin{array}{c}\text { Original } \\
\text { Sample }(\mathrm{O})\end{array}$ & $\begin{array}{c}\text { Sample } \\
\text { Mean (M) }\end{array}$ & $\begin{array}{c}\text { Standard } \\
\text { Deviation } \\
(, \text { STDEV },)\end{array}$ & $\begin{array}{c}\text { T-Statistics } \\
(|\mathrm{O} / \mathrm{STDEV}| .)\end{array}$ & p-values \\
\hline Organizational Culture ( X1.) -> (.Y) -> (.Z) & 0,220 & 0,216 & 0,072 & 3,051 & 0,002 \\
\hline Work Environment (.X2) -> (.Y) -> (.Z) & 0,407 & 0,404 & 0,093 & 4,354 & 0,000 \\
\hline
\end{tabular}

In view of the consequences of exploration on the way coefficient test can be found in Table V:

$\mathrm{H} 1$ is accepted that authoritative culture directionally affects work fulfillment through a path coefficient of 0.315 , $t$ statistic of 3.569 , p-value 0.000 . H2 is accepted that organizational culture has a positive directional impact on employee performance through the path coefficient $0.332, \mathrm{t}$ statistic 3.459, p-value 0.001. H3 accepted that job satisfaction has a positive directional impact on employee performance through the path coefficient 0.448 , $\mathrm{t}$ statistic is 3.991, p-value $0.000, \mathrm{H} 4$ is accepted by the work environment as having a positive directional impact on job satisfaction through the path coefficient 0.472 , $\mathrm{t}$ statistic 5.464, p-value 0.000. H5 is rejected, the work environment is proven to be unable to have a positive impact on employee performance through the path coefficient 0.083 , t statistic 0.818 , p-value 0.414 .

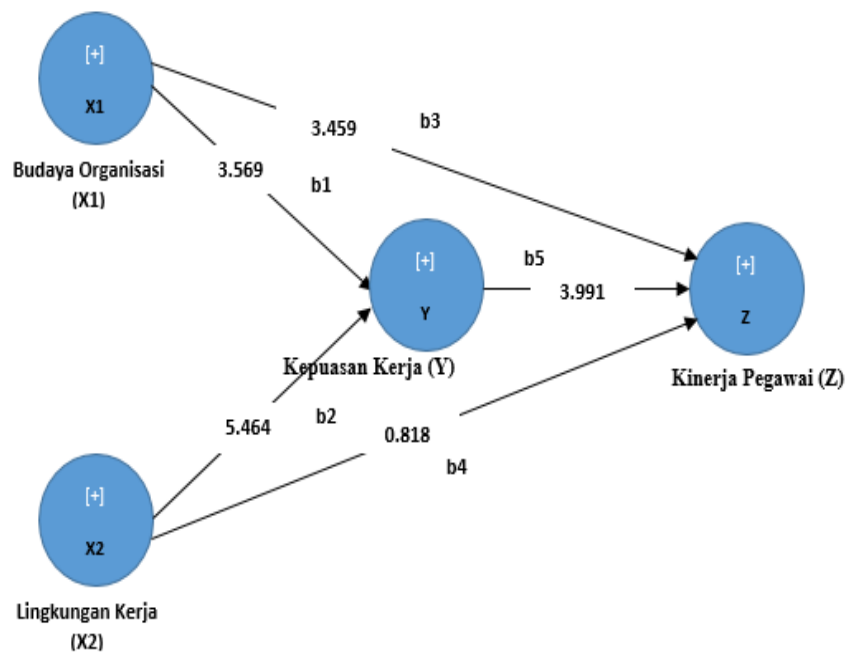

Fig. 3. Mediation Variable Testing Model.

In light of the aftereffects of the aberrant impact test in Table VI, it shows the following explanation:

H4: organizational culture has a positive impact on employee performance through job satisfaction through path coefficient 0.220 , t statistic 3.051 , p-value 0.002 .

$\mathrm{H} 5$ : the work environment has a positive directional impact on employee performance through job satisfaction through a path coefficient of 0.407 , $t$ statistic of 4.354 , the p-value of 0.000 .

\section{Predictive Relevance $\left(Q^{2}\right)$}

The value $\left(\mathrm{Q}^{2}\right)$ can be used to validate a model. The following are the results of the Predictive Relevance $\left(\mathrm{Q}^{2}\right)$ calculation that can be seen in this study.

TABEL VII: PREDictive Relevance $\left(\mathrm{Q}^{2}\right)$ Test Results

\begin{tabular}{cccc}
\hline Dependent variable & SSO & SSE & $\begin{array}{c}\mathrm{Q}^{2}(=1- \\
\text { SSE/SSO) }\end{array}$ \\
\hline Job Satisfaction $(\mathrm{Y})$ & $2.400,000$ & $1.936,927$ & 0,193 \\
Employee Performance $(\mathrm{Z})$ & $2.000,000$ & $1.450,897$ & 0,275 \\
\hline
\end{tabular}

The $\mathrm{Q}^{2}$ values obtained in this calculation are 0.193 and 0.275 , meaning that the structure obtained has good predictive relevance.

\section{CONCLUSIONN AND SUGGESTION}

\section{A. Conclusion}

In light of the consequences of the examination in this exploration at the West Jakarta Mayor's office, the provision of organizational culture has a positive impact on the fulfillment of the work of workers in the West Jakarta Mayor's office. That is, if the organizational culture in the West Jakarta Mayor's office can be carried out better, it will increase employee job satisfaction. The work environment has a positive impact on employee job satisfaction at the West Jakarta Mayor's office. That is, if the work environment in the West Jakarta Mayor's office is getting better, it will increase employee job satisfaction, organizational culture has a positive impact on employee performance at the West Jakarta Mayor's office. That is, if the application of organizational culture in the West Jakarta Mayor's office can be implemented better, it will improve employee performance. West, will improve employee performance.

\section{B. Suggestion}

It is necessary to maintain good communication between fellow employees in the work environment and strengthen teamwork or groups so that if there are difficulties in work, they can be overcome together which will ultimately improve employee performance. Provision of basic salary and incentive salary in accordance with the work performed. Employees will be very excited if the basic salary given is in accordance with the tasks that have been done. In addition, the incentive salary will encourage employees to be more active at work. If employees get a basic salary and incentive salaries will affect employee job satisfaction so that it will 
improve employee performance. The West Jakarta Mayor's Office needs to implement comfort in working because comfortable conditions can affect someone in doing work, this can be done by maintaining cleanliness in the workspace and facilitating the office as needed. The creation of a conducive environment can also make employees more active in their work and increase the moral support provided by their superiors. Thus it can improve employee performance.

\section{REFERENCES}

[1] Susetyo, 'Pengaruh Budaya Organisasi dan Lingkungan Kerja terhadap Kepuasan Kerja dan Kinerja Karyawan Pada PT Bank Muamalat Indonesia Divisi Konsumer Area Cabang Surabaya', Jurnal Ilmu Ekonomi dan Manajemen, 2016, DOI: 10.1177/01492063344543602.

[2] A. Raziq dan R. Maulabakhsh, ' Impact of Working Environment on Job Satisfaction.' Procedia Economics and Finance, vol. 23, 717-725, 2016.

[3] C. B. Purba dan P. N. Gunawan, 'The Influence of Work Motivation, Organizational Culture and Career Development on Employee Performance in PT. Titis Sampurna Inspection, Saudi Journal of Business and Management Studies, 2018, DOI: 10.21276/sjbms.2018.3.6.4.

[4] S. Haryanti dan M. Cholil, 'Pengaruh Gaya Kepemimpinan, Budaya Organisasi, Kompetensi Karyawan Terhadap Kinerja Dengan Komitmen Organisasi Sebagai Variabel Mediasi', Jurnal Bisnis \& Manajemen. vol.115, no.11, pp.333-44, 2015.

[5] T. Jayaweera, 'Impact of Work Environmental Factors on Job Performance, Mediating Role of Work Motivation: A Study of Hotel Sector in England,' International Journal of Business and Management, no. 3, 271-278, 2015.

[6] J. S. Tampubolon. M. H. Aima, dan B. Karsono, 'Effect of Social Needs and Award Needs on Job Satisfaction and Its Implementation on Employee Performance at PT. TUV NORD', 2019.

[7] A. Syahrum dan T. R. Rachmatullaily, 'Pengaruh Motivasi dan Kepuasan Kerja terhadap Kinerja Karyawan,' Jurnal Ilmu Manajemen, vol. 2, no. 4, pp. 566-574, 2019.

[8] Pranitasari dan Saputri, 'Pengaruh Budaya Organisasi dan Lingkungan Kerja Terhadap Motivasi Kerja Serta Dampaknya Terhadap Kepuasan Kerja Karyawan', Jurnal Riset Manajemen Sains Indonesia, vol. 11 no. 1, pp. 215-217, 2020

[9] M. Abouria dan S. Othman, 'Transformal Leadership, Job Satisfaction, Organizational Commitment, and Turnover Intentions: The Direct Effects among Bank Representatives', American Journal of Industrial and Business Management, vol. 7, 2017.

[10] J. Map. S. Mukmin. W. Budiarto, dan I. Prasetyo, 'Pengaruh Gaya Kepemimpinan dan Budaya Organisasi Terhadap Kinerja Karyawan Melalui Kepuasan Kerja Karyawan Sebagai Variabel Intervening, Jurnal Manajemen Dan Administrasi Publik, vol. 2, no. 3, pp. 72-84, 2019.

[11] R. Novrians, 'Pengaruh Budaya Organisasi Dan Lingkungan Kerja Pada Kinerja Dengan Kepuasan Kerja Sebagai Variabel Intervening (Studi Kasus Di Bulog Divre Jawa Timur).' Fakultas Ekonomi Universitas Islam Indonesia, 2018.

[12] Sedarmayanti, Manajemen Sumber Daya Manusia Perusahaan. Bandung: Remaja Rosdakarya, 2017.

[13] A. P. Mangkunegara, Pengaruh Budaya Organisasi dan Lingkungan Kerja terhadap Kinerja Pegawai dengan Kepuasan Kerja sebagai variabel mediasi', Journal of Social Sciences, vol. 3, no. 10, pp. 30-40, 2016.

[14] Romy, Budaya Organisasi. Bandung: Alfabeta, 2016.

[15] L. S. D. Irvianti, 'Pengaruh Lingkungan Kerja, Budaya Organisasi dan Komitmen Organisasi terhadap Kinerja Karyawan,' Journal of Management, vol. 7 no. 3, pp. 35-45, 2016.

[16] Wibowo, 'Pengaruh Kepuasan Kerja dan Lingkungan Kerja terhadap Kinerja Pegawai, Journal Psikolog, vol. 10, no. 5, pp. 45-55, 2017.

[17] Sugiyono, Metode Penelitian Pendidikan Pendekatan Kuantitatif Kualitatif, dan R\&D. Bandung: Alfabeta CV, 2017.

[18] Ghozali, Metode Analisis dengan Program PLS. Semarang: Badan penerbit UNDIP, 2016 